\title{
Article \\ Prevalence of and Factors Associated with Antibiotic Prescriptions in Patients with Acute Lower and Upper Respiratory Tract Infections-A Case-Control Study
}

\author{
Winfried V. Kern ${ }^{1}$ and Karel Kostev ${ }^{2, *}$ \\ 1 Department of Medicine II, Division of Infectious Diseases, University Hospital and Medical Center, \\ 79106 Freiburg, Germany; winfried.kern@uniklinik-freiburg.de \\ 2 Epidemiology, IQVIA Germany, 60549 Frankfurt am Main, Germany \\ * Correspondence: Karel.Kostev@iqvia.com; Tel.: +49-(0)69-6604-4878
}

Citation: Kern, W.V.; Kostev, K. Prevalence of and Factors Associated with Antibiotic Prescriptions in Patients with Acute Lower and Upper Respiratory Tract Infections-A Case-Control Study. Antibiotics 2021, 10, 455. https://doi.org/10.3390/ antibiotics10040455

Academic Editor: Albert Figueras

Received: 11 March 2021

Accepted: 13 April 2021

Published: 16 April 2021

Publisher's Note: MDPI stays neutral with regard to jurisdictional claims in published maps and institutional affiliations.

Copyright: (c) 2021 by the authors. Licensee MDPI, Basel, Switzerland. This article is an open access article distributed under the terms and conditions of the Creative Commons Attribution (CC BY) license (https:// creativecommons.org/licenses/by/ $4.0 /)$.

\begin{abstract}
Background: The goal of the present study was to estimate the prevalence of patient and physician related variables associated with antibiotic prescriptions in patients diagnosed with acute lower and upper respiratory tract infections (ALURTI), treated in general practices (GP) and pediatric practices, in Germany. Methods: The analysis included 1,140,095 adult individuals in 1237 general practices and 309,059 children and adolescents in 236 pediatric practices, from the Disease Analyzer database (IQVIA), who had received at least one diagnosis of an ALURTI between 1 January 2015 and 31 March 2019. We estimated the association between 35 predefined variables and antibiotic prescription using multivariate logistic regression models, separately for general and pediatric practices. The variables included the proportion (as a percentage) of antibiotics or phytopharmaceuticals on all prescriptions per practice, as an indicator of physician prescription preference. Results: The prevalence of antibiotic prescription was higher in patients treated in GP (31.2\%) than in pediatric practices $(9.1 \%)$. In GP, the strongest association with antibiotic prescription was seen in the practice preference for antibiotic use, followed by specific diagnoses (acute bronchitis, sinusitis, pharyngitis, laryngitis, and tracheitis), and higher patient age. In pediatric practices, acute sinusitis and bronchitis were the variables with the strongest association, followed by practice preference for antibiotic prescription. The strongest association with the non-prescription of antibiotics was practice preference for phytopharmaceuticals and the specific diagnosis of a viral infection. Conclusion: This study shows a high prevalence of antibiotic prescribing for patients with ALURTI in a primary care setting, especially in adult patients; physician related factors play an important role that should be addressed in interventions to reduce potentially inappropriate antibiotic prescribing.
\end{abstract}

Keywords: antibiotic prescription; primary care; risk factors; phytopharmaceutical; Germany

\section{Introduction}

Common colds, defined as acute lower and upper respiratory tract infections (ALURTI), are benign, self-limiting syndromes that include a group of diseases caused by several virus families. The severity and type of symptoms vary depending on the person and the pathogen [1]. ALURTI have a high prevalence worldwide. In Germany, the average 1-year prevalence of ALURTI in children and adolescents is about 89\% [2]. In adults, ALURTI occur less frequently.

Although physicians know that ALURTI are primarily caused by viruses, antibiotics are prescribed in many cases [3]. However, most patients suffering from ALURTI do not benefit from antibiotic treatment. Inappropriate use of antibiotics, in particular in the ambulatory setting and in veterinary medicine, contributes to an increasing bacterial drug resistance $[4,5]$ and is considered one of the major concerns to governments worldwide $[6,7]$. There is evidence of increasing environmental resistance that correlates with the use of these drugs and with their industrial-scale production [8]. The decreasing efficacy of 
antibacterial drugs has come with substantial costs that are expected to increase throughout future decades. One study has predicted that the cumulative global cost of antibiotic resistance might exceed 100 trillion USD [9]. It has been estimated that worldwide at least 700,000 people die annually as a result of resistant infections [9].

Data from Germany revealed that $40-45 \%$ of all outpatient antibiotic prescriptions were written by general practitioners [10]. Many of the antibiotic prescriptions were for patients with acute respiratory conditions, including sinusitis, pharyngitis, viral upper respiratory tract infections, bronchitis, and others [11], and a substantial proportion is likely to have been inappropriate. To reduce inappropriate antibiotic prescribing by physicians practicing in outpatient settings, it is important to better understand the variables associated with doctors' antibiotic prescribing decisions. No data are published yet on the frequency of inappropriate antibiotic use for ALURTI in Germany, and there are no data for factors associated with antibiotic prescriptions in patients with ALURTI in this country.

The goal of the present study was to estimate the prevalence of antibiotic use, and patient and physician related variables associated with antibiotic prescriptions in patients diagnosed with ALURTI, treated in general and pediatric practices in Germany.

\section{Methods}

\subsection{Data Source}

This study was based on data from the IMS Disease Analyzer database (IQVIA), which contains drug prescriptions, diagnoses, and basic medical and demographic data obtained directly, and in an anonymous format from computer systems used in the practices of general practitioners and specialists, including pediatricians [12]. The database covers approximately $3 \%$ of all outpatient practices in Germany. Diagnoses (according to International Classification of Diseases, 10th revision (ICD-10)), prescriptions (according to Anatomical Therapeutic Chemical (ATC) Classification system), and the quality of reported data, are monitored by IQVIA. The sampling method for the Disease Analyzer database is based on summary statistics from all doctors in Germany, published yearly by the German Medical Association. IQVIA uses these statistics to determine the panel design according to the following strata: specialist group, German federal state, community size category, and age of physician. The representativeness of the Disease Analyzer database has been previously verified [12].

\subsection{Study Population}

The analysis included patients who had received at least one diagnosis of ALURTI in 1237 general or 236 pediatric practices between January 1, 2015 and March 31, 2019. These diagnoses included: acute nasopharyngitis (J00), acute sinusitis (J01), acute pharyngitis (J02, excl. J02.0), acute laryngitis and tracheitis (J04), acute upper respiratory infections of multiple and unspecified sites (J06), acute bronchitis (J20, excl. J20.0, J20.1, and J20.2), unspecified acute lower respiratory infection (J22), bronchitis not specified as acute or chronic (J40), cough (R05), and viral infection of an unspecified site (B34).The first ALURTI diagnosis documented during this period was defined as the index date. Only patients who had been observed for a period of at least 12 months prior to the index date were included. Patients with a prescription for antibiotics (ATC code: J01) in the 30 days prior to the index date, and patients diagnosed with a bacterial infection (A38, J02.0, J03.0, J13-J15, $\mathrm{J} 16.0, \mathrm{~J} 20.0, \mathrm{~J} 20.1, \mathrm{~J} 20.2, \mathrm{~B} 95, \mathrm{~B} 96)$ at or in the 30 days prior to the index date, were excluded from the study (Figure 1). 


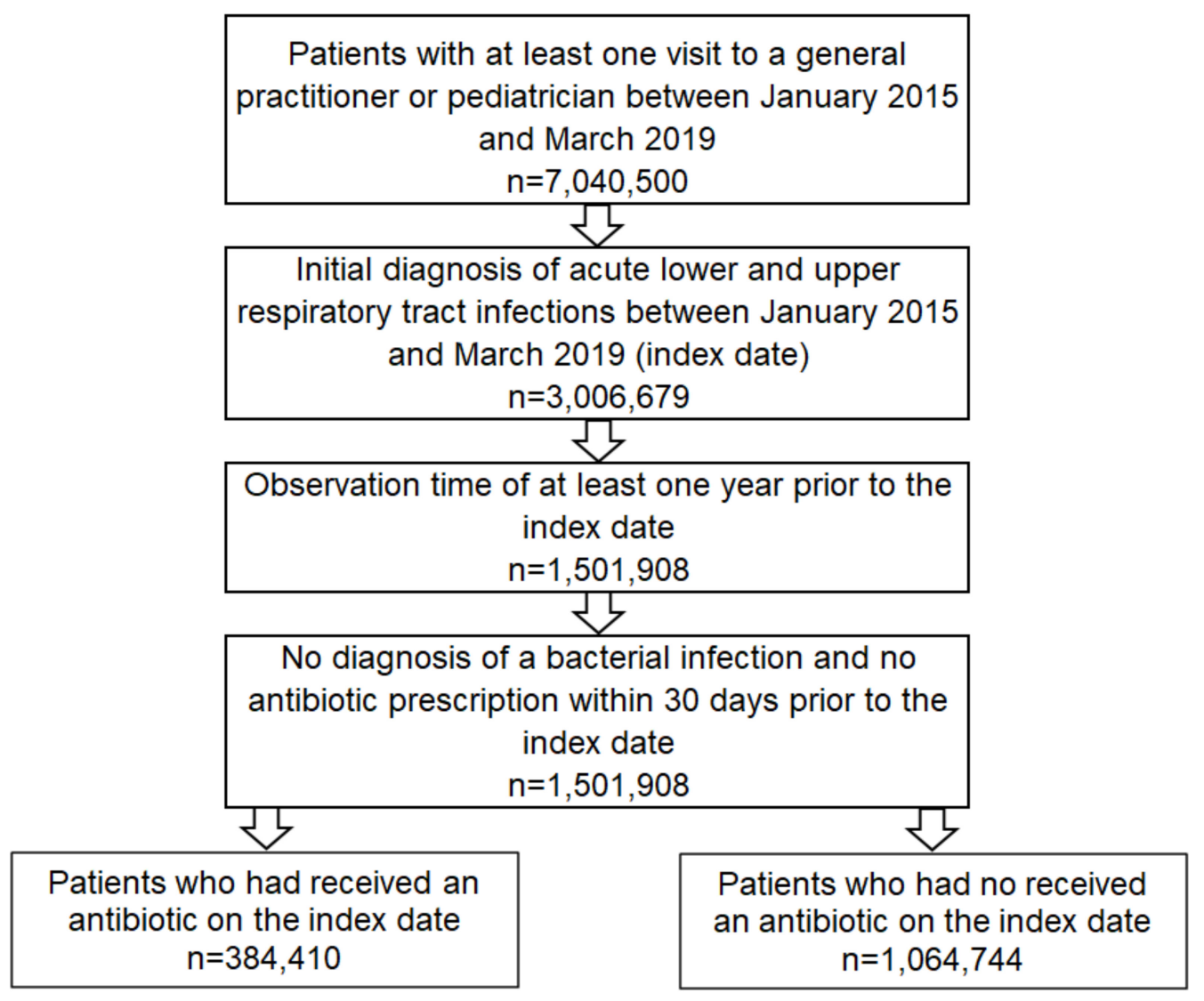

Figure 1. Selection of study patients from IMS Disease Analyzer database.

\subsection{Study Outcomes and Coviariables}

The main outcome of the study was the proportion of patients with ALURTI who received an antibiotic prescription on the day of diagnosis. Additionally, we estimated the association between predefined variables and antibiotic prescription. Variables used included age, sex, health insurance coverage, region (West versus East Germany), ALURTI diagnoses by ICD-10 codes, chronic co-diagnoses documented within 12 months prior to or on the index date (diabetes (ICD-10: E10-14)), ischemic heart disease/heart failure (ICD-10: E20-25, I50), renal failure (ICD-10: E10.2, E11.2, E14.2, N18, N19), cancer (ICD10: C00-C98), chronic obstructive lung disease (COPD) (ICD-10: J44), asthma (ICD-10: $\mathrm{J} 45)$ ), diagnosis of a bacterial infection within 365-31 days prior to the index date, and the total number of patients per practice and quarter. Finally, two variables were used to consider the extent of the antibiotic and phytopharmaceutical preference of each practice: average proportion of antibiotic prescription on all prescriptions per practice, and average proportion of phytopharmaceutical prescription on all prescriptions per practice within twelve months prior to the index date.

\subsection{Statistical Analyses}

The prevalence of antibiotic prescription was calculated as the number of patients with at least one antibiotic prescription on the index date by the number of all patents with ALURTI.

Patients were grouped by those who had received and those who had not received an antibiotic on the index date. Differences in the sample characteristics between those with and those without antibiotic prescriptions were tested using chi-squared tests for categorical variables and Wilcoxon rank sum tests (Mann-Whitney U test) for continuous variables. A multivariate logistic regression model was conducted to study the association between predefined variables and antibiotic prescription. This model was adjusted for all variables previously listed. Since the regression models contained up to 35 variables, 
a Bonferroni correction for $p$-value was performed, and a $p$ value of $<0.001$ (calculated as $<0.05 / 35$ ) was considered statistically significant. Furthermore, results were regarded as relevant or not when the odds ratio (OR) was $>1.25$ or $<0.75$, respectively. Fitness of the logistic model was checked using the Hosmer-Lemeshow statistic. As a sensitivity analysis, a random effect of practice was estimated.

All analyses were performed separately for patients treated by GPs and by pediatricians (children only). Analyses were carried out using SAS version 9.4 (SAS Institute, Cary, NC, USA).

\section{Results}

\subsection{Prevalence of Antibiotic Use}

In total, $1,449,154$ individuals $(1,140,095$ in general and 309,059 in pediatrician practices) were diagnosed with ALURTI between January 2015 and March 2019, and 384,410 $(26.5 \%)$ of them had received an antibiotic prescription on the day of diagnosis. The prevalence of antibiotic prescription was higher in patients treated in general $(31.2 \%)$ than in pediatric practices $(9.1 \%)$. By GPs, the highest antibiotic prescription prevalence was observed in patients with acute or non-specified bronchitis (54-57\%), acute sinusitis (52\%), and acute pharyngitis (46\%) (Figure 2). Interestingly, $1.5 \%$ of patients with the specific diagnosis of a viral infection of an unspecified site received an antibiotic prescription in GPs, $6.4 \%$ in pediatric practices (Figure 2).

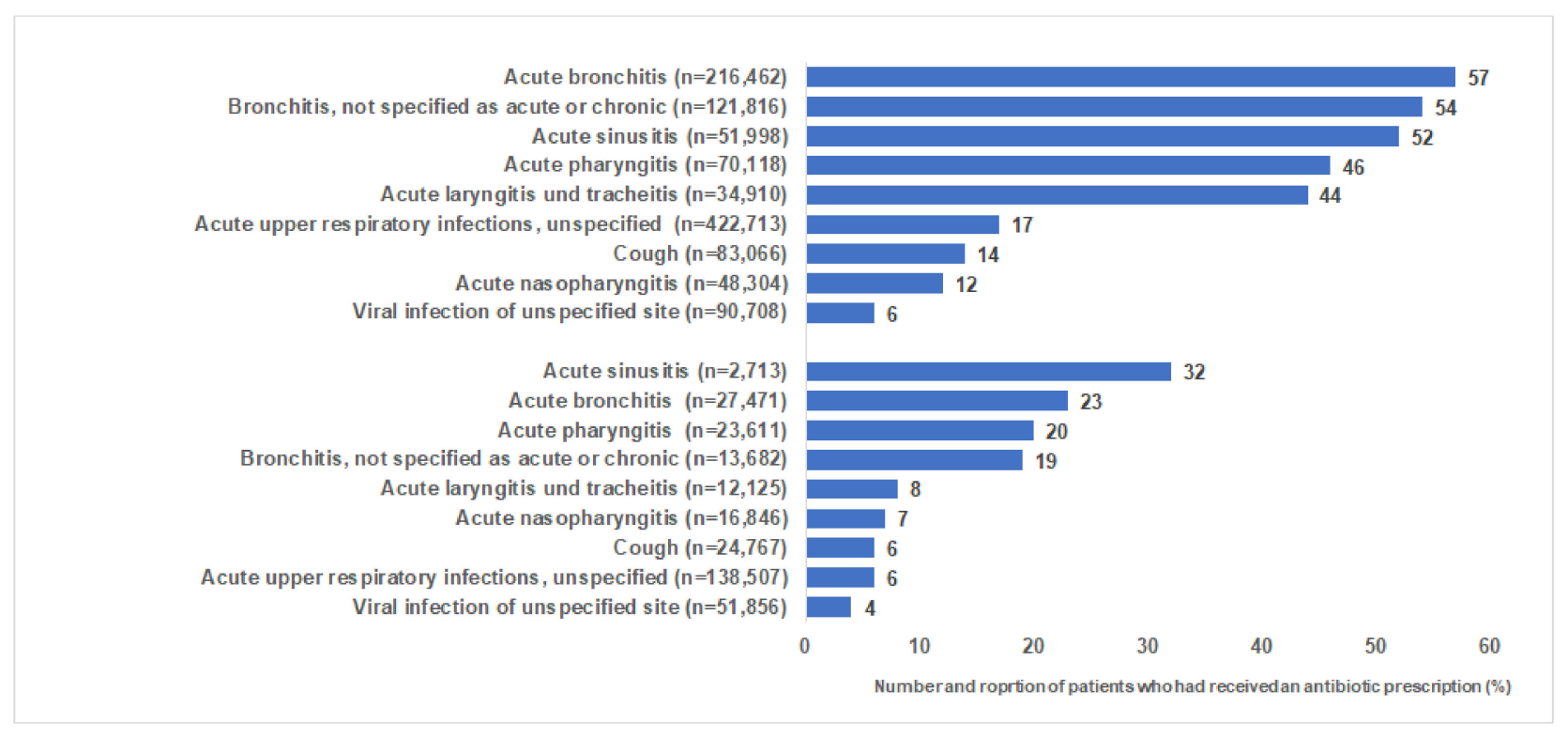

Figure 2. Proportion of patients who had received an antibiotic in general practices (GP) and pediatric practices.

When an antibiotic was prescribed, macrolides were the most common drug class by GPs (34\%), followed by cephalosporins ( $27 \%)$, and penicillins (21\%). In pediatric practices, cephalosporins $(44 \%)$ had the highest proportion, followed by a penicillin $(29 \%)$, and a macrolide (26\%).

\subsection{Characteristics of Patients with and without Antibiotic Prescription}

When comparing baseline characteristics of patients who had and who had not received an antibiotic prescription in general practices, patients receiving antibiotics were slightly older (51 vs. 46 years) and were more often diagnosed with an acute or nonspecified bronchitis, pharyngitis, sinusitis, laryngitis and tracheitis. Additionally, they had more often chronic co-diagnoses, were more often treated in practices preferring antibiotic therapy, and less likely in practices preferring phytopharmaceuticals (Table 1). In pediatric practices, patients receiving antibiotics were also older and more often diagnosed with an 
acute or non-specified bronchitis, pharyngitis, and sinusitis. Additionally, they had more often asthma diagnoses, were more frequently treated in practices preferring antibiotic therapy, and less frequently treated in practices preferring phytopharmaceuticals (Table 2).

Table 1. Baseline characteristics of study patients in GPs.

\begin{tabular}{|c|c|c|c|}
\hline Variable & $\begin{array}{l}\text { Patients with Antibiotic } \\
\text { Prescription (\%) }\end{array}$ & $\begin{array}{c}\text { Patients without Antibiotic } \\
\text { Prescription (\%) }\end{array}$ & $p$ Value \\
\hline$n$ & 356,045 & 784,050 & \multirow{3}{*}{$<0.001$} \\
\hline Age (Mean, SD) & $51.2(20.1)$ & $46.3(20.7)$ & \\
\hline Age $<18$ & 4.5 & 7.9 & \\
\hline Age $18-40$ & 26.5 & 32.4 & \multirow{5}{*}{$<0.001$} \\
\hline Age $41-50$ & 16.1 & 16.3 & \\
\hline Age 51-60 & 19.2 & 18.6 & \\
\hline Age 61-70 & 14.3 & 10.6 & \\
\hline Age 71-80 & 12.3 & 8.8 & \\
\hline Age $>80$ & 7.1 & 5.4 & \\
\hline Female sex $(\%)$ & 54.9 & 54.2 & $<0.001$ \\
\hline Private health insurance coverage $(\%)$ & 7.2 & 8.2 & $<0.001$ \\
\hline \multicolumn{4}{|l|}{$\begin{array}{c}\text { Acute lower and upper tract respiratory } \\
\text { infection diagnosis (\%) }\end{array}$} \\
\hline Viral infection of unspecified site & 1.5 & 10.9 & \multirow{9}{*}{$<0.001$} \\
\hline Acute nasopharyngitis & 1.6 & 5.4 & \\
\hline Acute sinusitis & 7.6 & 3.2 & \\
\hline Acute pharyngitis & 9.0 & 4.9 & \\
\hline Acute laryngitis and tracheitis & 4.3 & 2.5 & \\
\hline $\begin{array}{l}\text { Acute upper respiratory infections of multiple } \\
\text { and unspecified sites (J06) }\end{array}$ & 19.9 & 44.9 & \\
\hline Acute bronchitis & 34.5 & 11.9 & \\
\hline Bronchitis, not specified as acute or chronic & 18.3 & 7.2 & \\
\hline Cough & 3.3 & 9.1 & \\
\hline \multicolumn{4}{|l|}{$\begin{array}{c}\text { Co-Diagnoses (documented prior to or on the } \\
\text { index date) }(\%)\end{array}$} \\
\hline Diabetes & 6.2 & 4.4 & $<0.001$ \\
\hline Ischemic heart disease/heart failure & 5.3 & 4.8 & $<0.001$ \\
\hline Renal failure & 1.5 & 1.2 & $<0.001$ \\
\hline Cancer & 1.9 & 1.5 & 0.352 \\
\hline COPD & 3.3 & 1.9 & $<0.001$ \\
\hline Asthma & 3.6 & 2.7 & $<0.001$ \\
\hline $\begin{array}{l}\text { Diagnosis of a bacterial infection within } 365-31 \\
\text { days prior to the index date }(\%)\end{array}$ & 0.5 & 0.6 & 0.098 \\
\hline \multicolumn{4}{|l|}{ Number of patients per practice and quarter (\%) } \\
\hline$\leq 1000$ & 18.4 & 20.7 & \multirow{4}{*}{$<0.001$} \\
\hline $1001-1500$ & 34.4 & 38.3 & \\
\hline 1501-2000 & 25.4 & 22.5 & \\
\hline$>2000$ & 21.8 & 18.5 & \\
\hline Western Germany & 83.3 & 82.4 & $<0.001$ \\
\hline \multicolumn{4}{|l|}{$\begin{array}{l}\text { Proportion of antibiotic prescription on all } \\
\text { prescriptions per practice per year }\end{array}$} \\
\hline$\leq 4 \%$ & 3.0 & 8.6 & \multirow{5}{*}{$<0.001$} \\
\hline$>4-\leq 6 \%$ & 29.0 & 45.2 & \\
\hline$>6-\leq 8 \%$ & 34.8 & 29.6 & \\
\hline$>8-\leq 10 \%$ & 19.5 & 11.9 & \\
\hline$>10 \%$ & 13.7 & 4.7 & \\
\hline \multicolumn{4}{|l|}{$\begin{array}{l}\text { Proportion of phytopharmaceutical prescription } \\
\text { on all prescriptions per practice per year }(\%)\end{array}$} \\
\hline$\leq 1 \%$ & 39.4 & 37.1 & \multirow{5}{*}{$<0.001$} \\
\hline$>1-\leq 2 \%$ & 18.7 & 17.2 & \\
\hline$>2-\leq 3 \%$ & 15.0 & 14.9 & \\
\hline$>3-\leq 4 \%$ & 9.9 & 10.0 & \\
\hline$>\overline{4} \%$ & 17.0 & 20.8 & \\
\hline
\end{tabular}


Table 2. Baseline characteristics of study patients in pediatric practices.

\begin{tabular}{|c|c|c|c|}
\hline Variable & $\begin{array}{l}\text { Patients with Antibiotic } \\
\text { Prescription (\%) }\end{array}$ & $\begin{array}{l}\text { Patients without Antibiotic } \\
\text { Prescription }(\%)\end{array}$ & $p$ Value \\
\hline$n$ & 28,365 & 280,694 & \\
\hline Age (Mean, SD) & $7.9(4.7)$ & $7.6(4.4)$ & $<0.001$ \\
\hline \multicolumn{4}{|l|}{ Age $<18$} \\
\hline Age $2-5$ & 40.2 & 39.1 & \multirow{3}{*}{$<0.001$} \\
\hline Age 6-12 & 38.7 & 44.5 & \\
\hline Age $13-17$ & 21.1 & 16.4 & \\
\hline Female sex $(\%)$ & 49.4 & 48.4 & 1.000 \\
\hline Private health insurance coverage $(\%)$ & 9.6 & 9.5 & 0.635 \\
\hline \multicolumn{4}{|l|}{$\begin{array}{c}\text { Acute lower and upper tract respiratory } \\
\text { infection diagnosis }(\%)\end{array}$} \\
\hline Viral infection of unspecified site & 6.4 & 17.7 & $<0.001$ \\
\hline Acute nasopharyngitis & 4.2 & 5.6 & $<0.001$ \\
\hline Acute sinusitis & 3.1 & 0.6 & $<0.001$ \\
\hline Acute pharyngitis & 16.3 & 6.7 & $<0.001$ \\
\hline Acute laryngitis and tracheitis & 3.5 & 3.9 & $<0.001$ \\
\hline $\begin{array}{c}\text { Acute upper respiratory infections of multiple } \\
\text { and unspecified sites (J06) }\end{array}$ & 29.8 & 46.0 & $<0.001$ \\
\hline Acute bronchitis & 22.2 & 7.5 & $<0.001$ \\
\hline Bronchitis, not specified as acute or chronic & 9.3 & 3.9 & $<0.001$ \\
\hline Cough & 5.2 & 8.1 & $<0.001$ \\
\hline \multicolumn{4}{|l|}{$\begin{array}{c}\text { Co-Diagnoses (documented prior to or on the } \\
\text { index date) }(\%)\end{array}$} \\
\hline Diabetes & 0.1 & 0.1 & 0.294 \\
\hline Ischemic heart disease/heart failure & 0.1 & 0.1 & 0.096 \\
\hline Renal failure & 0.0 & 0.0 & 0.723 \\
\hline Cancer & 0.1 & 0.1 & 0.680 \\
\hline COPD & 4.7 & 4.2 & $<0.001$ \\
\hline Asthma & 3.4 & 2.9 & $<0.001$ \\
\hline $\begin{array}{c}\text { Diagnosis of a bacterial infection within } 365-31 \\
\text { days prior to the index date (\%) }\end{array}$ & 7.4 & 6.5 & $<0.001$ \\
\hline \multicolumn{4}{|l|}{ Number of patients per practice and quarter (\%) } \\
\hline$\leq 1000$ & 9.0 & 10.1 & \multirow{4}{*}{$<0.001$} \\
\hline $1001-1500$ & 34.5 & 37.5 & \\
\hline $1501-2000$ & 34.9 & 35.6 & \\
\hline$>2000$ & 21.6 & 16.8 & \\
\hline Western Germany (\%) & 85.6 & 83.0 & $<0.001$ \\
\hline \multicolumn{4}{|l|}{$\begin{array}{l}\text { Proportion of antibiotic prescription on all } \\
\text { prescriptions per practice per year }(\%)\end{array}$} \\
\hline$\leq 4 \%$ & 0.0 & 1.5 & \multirow{5}{*}{$<0.001$} \\
\hline$>4-\leq 6 \%$ & 4.5 & 11.4 & \\
\hline$>6-\leq 8 \%$ & 14.9 & 23.3 & \\
\hline$>8-\leq 10 \%$ & 27.8 & 29.0 & \\
\hline$>10 \%$ & 52.9 & 34.7 & \\
\hline \multicolumn{4}{|l|}{$\begin{array}{l}\text { Proportion of phytopharmaceutical prescription } \\
\text { on all prescriptions per practice per year }(\%)\end{array}$} \\
\hline$\leq 1 \%$ & 22.5 & 21.0 & \multirow{4}{*}{$<0.001$} \\
\hline$>\overline{1}-\leq 10$ & 32.9 & 31.6 & \\
\hline$>10-\leq 15 \%$ & 23.8 & 24.2 & \\
\hline$>1 \overline{5} \%$ & 20.8 & 23.2 & \\
\hline
\end{tabular}




\subsection{Variables Associated with an Antibiotic Prescription}

The results of the multivariate logistic regression model for GPs are displayed in Table 3. The probability of antibiotic prescription increased with higher age, especially for patients aged $>60$ years (ORs: 1.40-1.56). Diagnoses of acute bronchitis (OR: 6.01), non-specified bronchitis (OR: 5.22), acute sinusitis (OR: 5.32), acute pharyngitis (OR: 4.18), and acute laryngitis and tracheitis (OR: 3.87) were associated with an increased chance of receiving an antibiotic prescription, compared to ALURTI of multiple and unspecified sites. The antibiotic prescription prevalence was lower in Western than in Eastern Germany, while comorbidity obviously had only minor influences. The strongest association with antibiotic prescription was seen in the practice preference for antibiotics (Odds Ratio (OR): 5.23 for $>8-10 \%$ proportion of antibiotic prescription on all prescriptions per practice per year, and OR: 9.93 for $>10 \%$ proportion of antibiotic prescription on all prescriptions per practice per year, as compared to a proportion of $\leq 4 \%$ ). Conversely, practice preference for phytopharmaceuticals was negatively associated with antibiotic prescription (i.e., OR: 0.44 for $>4 \%$ of phytopharmaceutical prescription on all prescriptions per practice per year, as compared to $\leq 1 \%$ ), as was the diagnosis of a viral infection of unspecified site (OR: 0.32).

In pediatric practices (Table 4), the practice preference for antibiotics was also associated with an antibiotic prescription in patients with ALURTI (OR: 4.00 for $>10 \%$ proportion of antibiotic prescription on all prescriptions per practice per year, as compared to a proportion of $>4-6 \%$ ). Similar to the situation in general practices, preference for phytopharmaceuticals was negatively associated with antibiotic prescription (OR: $0.20-0.26$ for $>1 \%$ of phytopharmaceutical prescription on all prescriptions per practice per year, as compared to $\leq 1 \%$ ), as was the diagnosis of a viral infection of unspecified site (OR: 0.57 ). Diagnoses of acute sinusitis (OR: 7.14), acute bronchitis (OR: 4.55), acute pharyngitis (OR: 3.57), non-specified bronchitis (OR: 3.43), acute laryngitis and tracheitis (OR: 1.43), acute nasopharyngitis (OR: 1.20), cancer as an underlying disease (OR: 1,81), and practice size of $>2000$ patients per quarter (OR: 1.35) were positively associated with increased chance of receiving antibiotic prescription. A random effect of practice variable was not significant (OR: 1.00).

Table 3. Variables associated with an antibiotic prescription in patients diagnosed with an acute lower or upper respiratory tract infection in GPs.

\begin{tabular}{|c|c|c|}
\hline Variable & Odds Ratio (95\% CI) & $p$ Value * \\
\hline Age $18-40$ & Reference & \\
\hline Age $41-50$ & $1.20(1.18-1.22)$ & $<0.001$ \\
\hline Age $51-60$ & $1.25(1.23-1.27)$ & $<0.001$ \\
\hline Age $61-70$ & $1.55(1.52-1.58)$ & $<0.001$ \\
\hline Age $71-80$ & $1.56(1.53-1.59)$ & $<0.001$ \\
\hline Age $>80$ & $1.40(1.37-1.44)$ & $<0.001$ \\
\hline Female & Reference & \\
\hline Male & $0.99(0.98-1.00)$ & 0.088 \\
\hline Statutory health insurance & Reference & \\
\hline Private health insurance & $0.89(0.87-0.91)$ & $<0.001$ \\
\hline Acute upper respiratory infections of multiple and unspecified sites & Reference & \\
\hline Viral infection of unspecified site & $0.32(0.32-0.33)$ & $<0.001$ \\
\hline Acute nasopharyngitis & $0.66(0.64-0.68)$ & $<0.001$ \\
\hline Acute sinusitis & $5.32(5.21-5.44)$ & $<0.001$ \\
\hline Acute pharyngitis & $4.18(4.10-4.27)$ & $<0.001$ \\
\hline Acute laryngitis and tracheitis & $3.87(3.77-3.98)$ & $<0.001$ \\
\hline Acute bronchitis & $6.01(5.93-6.10)$ & $<0.001$ \\
\hline Bronchitis, not specified as acute or chronic & $5.22(5.13-5.30)$ & $<0.001$ \\
\hline Cough & $0.77(0.75-0.79)$ & $<0.001$ \\
\hline
\end{tabular}


Table 3. Conts.

\begin{tabular}{|c|c|c|}
\hline Variable & Odds Ratio (95\% CI) & $p$ Value * \\
\hline \multicolumn{3}{|l|}{ Co-Diagnoses (documented prior to or on the index date) } \\
\hline Diabetes & $1.07(1.05-1.09)$ & $<0.001$ \\
\hline Ischemic heart disease/heart failure & $1.01(0.98-1.03)$ & 0.492 \\
\hline Renal failure & $0.90(0.86-0.93)$ & $<0.001$ \\
\hline Cancer & $0.97(0.93-1.00)$ & 0.061 \\
\hline COPD & $1.24(1.20-1.27)$ & $<0.001$ \\
\hline Asthma & $1.13(1.10-1.16)$ & $<0.001$ \\
\hline $\begin{array}{l}\text { Diagnosis of a bacterial infection within 365-30 days prior to the } \\
\text { index date }\end{array}$ & $1.00(0.93-1.07)$ & 0.894 \\
\hline \multicolumn{3}{|l|}{ Number of patients per practice and quarter } \\
\hline$\leq 1000$ & Reference & \\
\hline $1001-1500$ & $1.03(1.02-1.05)$ & $<0.001$ \\
\hline $1501-2000$ & $1.03(1.01-1.04)$ & $<0.001$ \\
\hline$>2000$ & $1.08(1.06-1.10)$ & $<0.001$ \\
\hline Western Germany & $0.73(0.72-0.74)$ & $<0.001$ \\
\hline Eastern Germany & Reference & \\
\hline \multicolumn{3}{|l|}{$\begin{array}{l}\text { Proportion of antibiotic prescription on all prescriptions per practice } \\
\text { per year }\end{array}$} \\
\hline$\leq 4$ & Reference & \\
\hline$>4-\leq 6$ & $2.16(2.10-2.21)$ & $<0.001$ \\
\hline$>6-\leq 8$ & $3.95(3.84-4.05)$ & $<0.001$ \\
\hline$>8-\leq 10$ & $5.23(5.09-5.38)$ & $<0.001$ \\
\hline$>\overline{10}$ & $9.93(9.62-10.24)$ & $<0.001$ \\
\hline \multicolumn{3}{|l|}{$\begin{array}{c}\text { Proportion of phytopharmaceutical prescription on all prescriptions } \\
\text { per practice per year }\end{array}$} \\
\hline$\leq 1$ & Reference & \\
\hline$>1-\leq 2$ & $0.89(0.88-0.90)$ & $<0.001$ \\
\hline$>2-\leq 3$ & $0.64(0.63-0.66)$ & $<0.001$ \\
\hline$>3-\leq 4$ & $0.66(0.64-0.68)$ & $<0.001$ \\
\hline$>4$ & $0.44(0.43-0.46)$ & $<0.001$ \\
\hline
\end{tabular}

* Significance values $<0.001$ were recorded when the odds ratio (OR) was $>1.25$ or $<0.75$, respectively, as these effects were regarded as relevant.

Table 4. Variables associated with an antibiotic prescription in patients diagnosed with an acute lower and upper respiratory tract infection diagnosis in pediatric practices.

\begin{tabular}{ccc}
\hline Variable & Odds Ratio (95\% CI) & $p$ Value * \\
Age 2-5 & Reference & \\
Age 6-12 & $0.85(0.82-0.88)$ & \\
Age 13-17 & $1.21(1.16-1.26)$ & $<.001$ \\
Female sex & Reference & $<0.001$ \\
Male sex & $0.94(0.91-0.97)$ & $<0.001$ \\
Statutory health insurance coverage & Reference & \\
Private health insurance coverage & $1.03(0.98-1.09)$ & \\
Acute lower and upper respiratory tract infection diagnosis & $0.57(0.54-0.61)$ & $<.289$ \\
Viral infection of unspecified site & $1.20(1.12-1.29)$ & $<.001$ \\
Acute nasopharyngitis & $7.14(6.44-7.91)$ & $<0.001$ \\
Acute sinusitis & $3.57(3.39-3.75)$ & $<0.001$ \\
Acute pharyngitis & $1.43(1.32-1.55)$ & $<0.001$ \\
Acute laryngitis and tracheitis & Reference & $<0.001$ \\
Acute upper respiratory infections of multiple and unspecified sites (J06) & $4.55(4.35-4.76)$ & $<0.001$ \\
Acute bronchitis & $3.43(3.23-3.64)$ & $<0.001$ \\
Bronchitis, not specified as acute or chronic & $1.18(1.11-1.26)$ & $<0.001$ \\
\hline
\end{tabular}


Table 4. Conts.

\begin{tabular}{|c|c|c|}
\hline Variable & Odds Ratio (95\% CI) & $p$ Value * \\
\hline \multicolumn{3}{|l|}{ Co-Diagnoses (documented prior to or on the index date) } \\
\hline Diabetes & $0.89(0.59-1.32)$ & 0.552 \\
\hline Ischemic heart disease/heart failure & $1.75(1.10-2.78)$ & 0.033 \\
\hline Renal failure & $1.07(0.24-4.83)$ & 0.926 \\
\hline Cancer & $1.81(1.15-2.86)$ & 0.019 \\
\hline COPD & $1.10(1.03-1.18)$ & 0.005 \\
\hline Asthma & $0.88(0.82-0.95)$ & 0.002 \\
\hline Diagnosis of a bacterial infection within $365-30$ days prior to the index date & $1.09(1.03-1.16)$ & 0.002 \\
\hline \multicolumn{3}{|l|}{ Number of patients per practice and quarter } \\
\hline$\leq 1000$ & Reference & \\
\hline $1001-1500$ & $1.14(1.07-1.21)$ & $<0.001$ \\
\hline $1501-2000$ & $1.20(1.13-1.27)$ & $<0.001$ \\
\hline$>2000$ & $1.35(1.26-1.43)$ & $<0.001$ \\
\hline Eastern Germany & Reference & \\
\hline Western Germany & $1.07(1.02-1.13)$ & 0.006 \\
\hline \multicolumn{3}{|l|}{$\begin{array}{c}\text { Proportion of antibiotic prescription on all prescriptions per practice per } \\
\text { year }\end{array}$} \\
\hline$>4-\leq 6$ & Reference & \\
\hline$>6-\leq 8$ & $1.62(1.49-1.75)$ & $<0.001$ \\
\hline$>8-\leq 10$ & $2.41(2.24-2.60)$ & $<0.001$ \\
\hline$>10$ & $4.00(3.71-3.30)$ & $<0.001$ \\
\hline \multicolumn{3}{|l|}{$\begin{array}{c}\text { Proportion of phytopharmaceutical prescription on all prescriptions per } \\
\text { practice per year }\end{array}$} \\
\hline$\leq 1$ & Reference & \\
\hline$>1-\leq 10$ & $0.20(0.18-0.23)$ & $<0.001$ \\
\hline$>10-\leq 15$ & $0.24(0.87-0.97)$ & $<0.001$ \\
\hline$>1 \overline{5}$ & $0.26(0.23-0.30)$ & $<0.001$ \\
\hline
\end{tabular}

* Significance values $<0.001$ were recorded when the odds ratio (OR) was $>1.25$ or $<0.75$, respectively, as these effects were regarded as relevant.

\section{Discussion}

This study, conducted in general and pediatric practices in Germany and based on more than one million individuals, resulted in three key findings. First, the recent prevalence of antibiotic prescription in adults with ALURTI was high (31.2\%) and associated with age, coded infection diagnosis, and geography. Second, practice-level variables indicating frequent prescription of antibiotics or phytopharmaceuticals had independent associations with antibiotic prescription prevalence, both in general as well as in pediatric practices. Third, antibiotic prescription prevalence among children with ALURTI was low $(<10 \%)$ and associated with coded infection diagnosis, cancer as an underlying disease, and practice size in addition to practice preference for antibiotics.

Antibiotics are an important therapy option for bacterial infections and can save lives, provided the correct indication, dose, and duration of therapy. However, in the case of an ALURTI, there is usually no indication for an antibiotic prescription since the majority of such infections are of viral origin, and even in cases of bacterial origin, only a minority of patients benefit from antibiotic treatment. According to a systematic review, there is no difference in the outcomes between patients with immediate and delayed antibiotic use [13]. A more recent randomized trial showed that strategies of no or delayed antibiotic prescription result in similar symptomatic outcomes as immediate prescription and are not associated with patients' beliefs in the effectiveness of antibiotics [14]. An investigation of patients' expectations as a reason for prescribing antibiotics for common upper respiratory tract infections reported, that although $11 \%$ of patients may have expected an antibiotic prescription, most of them indicated they would trust their physician when he or she deems a prescription unnecessary [15]. 
Prescribing physician-level factors may be critically affecting antibiotic prescribing for patients with ALURTI. O'Connor et al., for example, identified that a higher number of patients per day resulting in shorter consultations, as well as a doctors' professional training and their career stage were significant factors [16]. Practice size estimated by the number of patients per practice and quarter as a factor for antibiotic prescribing was also found in other studies from Canada [17] and Norway [18], as well as in the present study, in particular regarding pediatric practices. Other physician-level factors for antibiotic prescribing are diagnostic uncertainty and fear of complications [19]. This may be a reason why the prevalence of antibiotic use in our study was high in acute bronchitis patients, as the likelihood of confusing acute bronchitis and pneumonia is higher than in the case of upper tract respiratory infection [20]. More difficult to understand is the relatively frequent prescription of antibiotics in patients diagnosed with acute sinusitis in the present work. A Cochrane review concluded that the potential benefit of antibiotics to treat acute rhinosinusitis was marginal and that antibiotics are not a first-choice treatment for adults with short-duration sinus infections [21]. In acute non-bacterial laryngitis, the use of antibiotics is also considered not appropriate [22]. We were unable to assess and include clinical severity at presentation as a confounder variable, perhaps explaining the prescription patterns for sinusitis. Coding mild sinusitis as nasopharyngitis (J00) or an acute upper respiratory infection (J06) versus coding more severe or complicated cases as acute sinusitis (J01) may have confounded our analysis. As in other studies [23-25], the prevalence of antibiotic prescriptions was higher in individuals with comorbidity, and this may be related to difficulties in distinguishing between bacterial and viral infections in everyday practice and in trying to prevent serious complications [26].

An interesting finding in our study was the association between practice preference for phytotherapy and lower antibiotic prescribing rates, both in adults and children. There is some evidence that the use of phytopharmaceuticals could contribute to a reduction in the number of inappropriate antibiotic prescriptions for respiratory infections; in a recent study based on the electronic medical records from approximately 234,000 primary care and pediatric patients in Germany, the use of selected phytopharmaceuticals in ALURTI was associated with a reduced need for antibiotic prescriptions in the further course of the disease [27]. Reviews of complementary and alternative medicines for treatment of respiratory tract infections indicate that some of the treatments may be effective and safe, and help to reduce unnecessary antibiotic prescribing [28-33].

A strength of this study is the large sample size. This is, however, also the study limitation, as every minor difference becomes highly significant with large patient samples. Further limitations include the lack of several potentially confounding factors, such as disease severity, patients' sociocultural variables, and patients' preference of antibiotics. An additional limitation of the present study was the unavailability of possible point-ofcare test results as a possible confounder. We could not assess the coding accuracy and consistency. The fact that explored covariates are very general, in line with the registry intention of the database, should be noted.

In addition, the study reflects the German healthcare system, and its results may not be generalizable to other countries.

\section{Conclusions}

In conclusion, we show a relatively high recent prevalence of potentially inappropriate antibiotic prescribing for adult patients with ALURTI in a primary care setting. Practice related factors, including antibiotic preference, seemed to play an important role in prescribing prevalence and should be studied in more detail in order to design interventions to further reduce inappropriate antibiotic use.

Author Contributions: Conceptualization, K.K.; Methodology K.K.; Validation, W.V.K.; Formal Analysis, K.K.; Investigation, K.K.; Writing-Original Draft Preparation, K.K.; Writing-Review and Editing, W.V.K. All authors have read and agreed to the published version of the manuscript. 
Funding: This study was funded by Dr. Wilmar Schwabe GmbH \& Co.KG, Karlsruhe, Deutschland.

Institutional Review Board Statement: The study was conducted according to the guidelines of the Declaration of Helsinki, and approved by the Institutional Review Board.

Informed Consent Statement: German law allows the use of anonymous electronic medical records for research purposes under certain conditions. According to this legislation, it is not necessary to obtain informed consent from patients or approval from a medical ethics committee for this type of observational study that contains no directly identifiable data. Because patients were only queried as aggregates and no protected health information was available for queries, no IRB approval was required for the use of this database or the completion of this study.

Data Availability Statement: Data is contained within the article.

Conflicts of Interest: K.K. is an employee of IQVIA, with no further conflicts of interest. W.V.K. declares that he has no competing interests.

\section{References}

1. Allan, G.M.; Arroll, B. Prevention and treatment of the common cold: Making sense of the evidence. CMAJ 2014, 186, 190-199. [CrossRef] [PubMed]

2. Eckel, N.; Sarganas, G.; Wolf, I.K.; Knopf, H. Pharmacoepidemiology of common colds and upper respiratory tract infections in children and adolescents in Germany. BMC Pharmacol. Toxicol. 2014, 15, 44. [CrossRef]

3. Altiner, A.; Bell, J.; Duerden, M.; Essack, S.; Kozlov, R.; Noonan, L.; Oxford, J.; Pignatari, A.C.C.; Sessa, A.; Velden, A. More action, less resistance: Report of the 2014 Summit of the Global Respiratory Infection Partnership. Int. J. Pharm. Pract. 2015, 23, 370-377. [CrossRef]

4. Köchling, A.; Löffler, C.; Reinsch, S.; Hornung, A.; Böhmer, F.; Altiner, A.; Chenot, J.F. Reduction of antibiotic prescriptions for acute respiratory tract infections in primary care: A systematic review. Implement. Sci. 2018, 13, 47. [CrossRef]

5. Davies, J.; Davies, D. Origins and evolution of antibiotic resistance. Microbiol. Mol. Biol. Rev. 2010, 74, 417-433. [CrossRef]

6. Tanday, S. Resisting the use of antibiotics for viral infections. Lancet Respir. Med. 2016, 4, 179. [CrossRef]

7. Hernando-Amado, S.; Coque, T.M.; Baquero, F.; Martínez, J.L. Antibiotic Resistance: Moving from Individual Health Norms to Social Norms in One Health and Global Health. Front. Microbiol. 2020, 11, 1914. [CrossRef]

8. Knapp, C.W.; Dolfing, J.; Ehlert, P.A.; Graham, D.W. Evidence of increasing antibiotic resistance gene abundances in archived soils since 1940. Environ. Sci. Technol. 2010, 44, 580-587. [CrossRef] [PubMed]

9. O'Neill, J. Tackling Drug-Resistant Infections Globally: Final Report and Recommendations. amr-review.org. 2016. Available online: https:/ /amr-review.org/sites/default/files/160518_Final\%20paper_with\%20cover.pdf. (accessed on 3 April 2021).

10. Kern, W.V.; Schaufler, J.; Telschow, C. Antibiotikaverbrauch im ambulanten Bereich. In Bundesamt für Verbraucherschutz und Lebensmittelsicherheit, Paul-Ehrlich-Gesellschaft für Chemotherapie e.V. GERMAP 2015-Bericht über den Antibiotikaverbrauch und die Verbreitung von Antibiotikaresistenzen in der Human- und Veterinärmedizin in Deutschland; Antiinfectives Intelligence: Rheinbach, Germany, 2016.

11. Zetts, R.M.; Stoesz, A.; Smith, B.A.; Hyun, D.Y. Outpatient Antibiotic Use and the Need for Increased Antibiotic Stewardship Efforts. Pediatrics 2018, 141, e20174124. [CrossRef]

12. Rathmann, W.; Bongaerts, B.; Carius, H.J.; Kruppert, S.; Kostev, K. Basic characteristics and representativeness of the German Disease Analyzer database. Int. J. Clin. Pharmacol. Ther. 2018, 56, 459-466. [CrossRef] [PubMed]

13. Spurling, G.K.; Del Mar, C.B.; Dooley, L.; Foxlee, R. Delayed antibiotics for symptoms and complications of respiratory infections. Cochrane Database Syst. Rev. 2004, 18, CD004417.

14. Little, P.; Moore, M.; Kelly, J.; Williamson, I.; Leydon, G.; McDermott, L.; Mullee, M.; Stuart, B.; PIPS Investigators. Delayed antibiotic prescribing strategies for respiratory tract infections in primary care: Pragmatic, factorial, randomised controlled trial. BMJ 2014, 348, g1606. [CrossRef]

15. Faber, M.S.; Heckenbach, K.; Velasco, E.; Eckmanns, T. Antibiotics for the common cold: Expectations of Germany's general population. Euro Surveill. 2010, 15, 19655. Available online: http:/ /www.eurosurveillance.org/View Article.aspx?ArticleId=1965 (accessed on 3 February 2021). [CrossRef]

16. O'Connor, R.; O'Doherty, J.; O'Regan, A.; Dunne, C. Antibiotic use for acute respiratory tract infections (ARTI) in primary care; what factors affect prescribing and why is it important? A narrative review. Ir. J. Med. Sci. 2018, 187, 969-986. [CrossRef] [PubMed]

17. Silverman, M.; Povitz, M.; Sontrop, J.M.; Li, L.; Richard, L.; Cejic, S.; Shariff, S.Z. Antibiotic prescribing for nonbacterial acute upper respiratory infections in elderly persons. Ann. Intern. Med. 2017, 166, 765-777. [CrossRef] [PubMed]

18. Lindberg, B.H.; Gjelstad, S.; Foshaug, M.; Høye, S. Antibiotic prescribing for acute respiratory tract infections in Norwegian primary care out-of-hours service. Scand. J. Prim. Health Care 2017, 35, 178-185. [CrossRef]

19. Ackerman, S.L.; Gonzales, R.; Stahl, M.S.; Metlay, J.P. One size does not fit all: Evaluating an intervention to reduce antibiotic prescribing for acute bronchitis. BMC Health Serv. Res. 2013, 4, 462. [CrossRef] [PubMed]

20. Moore, M.; Stuart, B.; Little, P.; Smith, S.; Thompson, M.J.; Knox, K.; van den Bruel, A.; Lown, M.; Mant, D. Predictors of pneumonia in lower respiratory tract infections: 3C prospective cough complication cohort study. Eur. Respir. J. 2017, 50, 1700434. [CrossRef] [PubMed] 
21. Lemiengre, M.B.; van Driel, M.L.; Merenstein, D.; Liira, H.; Mäkelä, M.; De Sutter, A.I. Antibiotics for acute rhinosinusitis in adults. Cochrane Database Syst. Rev. 2018, 9, CD006089. [CrossRef] [PubMed]

22. Undeland, D.K.; Kowalski, T.J.; Berth, W.L.; Gundrum, J.D. Appropriately prescribing antibiotics for patients with pharyngitis: A physician-based approach vs a nurse-only triage and treatment algorithm. Mayo Clin. Proc. 2010, 85, 1011-1015. [CrossRef]

23. Li, W.; Ding, C.; Yin, S. Severe pneumonia in the elderly: A multivariate analysis of risk factors. Int. J. Clin. Exp. Med. 2015, 8, 12463-12475. [PubMed]

24. Kornum, J.B.; Thomsen, R.W.; Riis, A.; Lervang, H.H.; Schønheyder, H.C.; Sørensen, H.T. Diabetes, glycemic control, and risk of hospitalization with pneumonia: A population-based case-control study. Diabetes Care 2008, 31, 1541-1545. [CrossRef] [PubMed]

25. Wong, J.L.; Evans, S.E. Bacterial Pneumonia in Patients with Cancer: Novel Risk Factors and Management. Clin. Chest Med. 2017, 38, 263-277. [CrossRef] [PubMed]

26. Petursson, P. GPs' reasons for "non-pharmacological" prescribing of antibiotics A phenomenological study. Scand. J. Prim. Health Care 2005, 23, 120-125. [CrossRef]

27. Martin, D.; Konrad, M.; Adarkwah, C.C.; Kostev, K. Reduced antibiotic use after initial treatment of acute respiratory infections with phytopharmaceuticals-A retrospective cohort study. Postgrad. Med. 2020, 132, 412-418. [CrossRef]

28. Wopker, P.M.; Schwermer, M.; Sommer, S.; Längler, A.; Fetz, K.; Ostermann, T.; Zuzak, T.J. Complementary and alternative medicine in the treatment of acute bronchitis in children: A systematic review. Complement. Ther. Med. 2020, 49, 102217. [CrossRef]

29. Willcox, M.; Donovan, E.; Hu, X.Y.; Elboray, S.; Jerrard, N.; Roberts, N.; Santer, M. Views regarding use of complementary therapies for acute respiratory infections: Systematic review of qualitative studies. Complement. Ther. Med. 2020, 50, 102382. [CrossRef]

30. Timmer, A.; Günther, J.; Motschall, E.; Rücker, G.; Antes, G.; Kern, W.V. Pelargonium sidoides extract for treating acute respiratory tract infections. Cochrane Database Syst. Rev. 2013, 22, CD006323. [CrossRef]

31. Baars, E.W.; Belt-van Zoen, E.; Breitkreuz, T.; Martin, D.; Matthes, H.; von Schoen-Angerer, T.; Soldner, G.; Vagedes, J.; van Wietmarschen, H.; Patijn, O.; et al. Corrigendum to "The Contribution of Complementary and Alternative Medicine to Reduce Antibiotic Use: A Narrative Review of Health Concepts, Prevention, and Treatment Strategies". Evid. Based Complement. Alternat. Med. 2020, 2020, 7089287. [CrossRef]

32. Anheyer, D.; Cramer, H.; Lauche, R.; Saha, F.J.; Dobos, G. Herbal Medicine in Children with Respiratory Tract Infection: Systematic Review and Meta-Analysis. Acad. Pediatr. 2018, 18, 8-19. [CrossRef]

33. Koch, A.K.; Klose PLauche, R.; Cramer, H.; Baasch, J.; Dobos, G.J.; Langhorst, J. A Systematic Review of Phytotherapy for Acute Rhinosinusitis. Forsch. Komplementmed. 2016, 23, 165-169. [CrossRef] [PubMed] 